\section{Nexus between corporate characteristics and financial reporting timelines: evidence from the Saudi Stock Exchange}

Timeliness of financial reporting

\author{
Ibrahim El-Sayed Ebaid
}

Department of Accounting, Faculty of Commerce, Tanta University, Tanta, Egypt
Received 29 August 2021 Revised 31 October 2021 Accepted 27 January 2022

\begin{abstract}
Purpose - The purpose of this study is to examine the nexus between corporate characteristics and timeliness of financial reporting in Saudi Arabia. Specifically, this study investigates the relationship between financial reporting timeliness and both corporate size, profitability, leverage and institutional ownership.

Design/methodology/approach - A sample of 67 of nonfinancial companies listed in the Saudi market during the period 2015-2018 was used. Multivariate regression analysis was performed to analyze the relationship between the four corporate characteristics and timeliness of financial reporting.

Findings - The findings revealed that financial reporting timeliness is significantly correlated with three of the corporate's characteristics, which are company size, profitability and leverage, while there is no significant effect of institutional ownership on the timeliness of financial reporting.

Research limitations/implications - The findings of this study may not be generalizable to all companies listed in the Saudi market as a result of limiting the study to nonfinancial companies and excluding financial companies from the sample. Future research may explore the determinants of the timeliness of these companies' financial reporting.

Practical implications - Given the significant interest expressed by investors, regulators and researchers in the field of financial reporting timeliness, especially in emerging markets where financial reports are almost the main and only source of information, this study highlights the role that corporate characteristics play in influencing the financial reporting timeliness in Saudi Arabia as one of emerging markets.

Originality/value - Despite the importance of financial reporting timeliness, there are very few studies that have examined this issue in Saudi Arabia. This study contributes to bridging this gap by examining the relationship between the corporate characteristics and the timeliness of financial reports.
\end{abstract}

Keywords Company size, Profitability, Leverage, Institutional ownership, Financial reporting timeliness, Saudi Arabia

Paper type Research paper

\section{Introduction}

The main purpose of financial reporting is to provide financial information that benefits current or prospective investors, lenders and other stakeholders in making economic decisions. For financial information to be useful in making decisions, it must have certain qualitative characteristics. According to the framework for preparation and presentation of financial statements issued by the International Accounting Standards Board (IASB, 2010), these qualitative characteristics include fundamental characteristics (i.e. relevance and faithful representation) and enhancing characteristics (i.e. comparability and understandability). The framework for preparation and presentation of financial

(C) Ibrahim El-Sayed Ebaid. Published in Journal of Money and Business. Published by Emerald Publishing Limited. This article is published under the Creative Commons Attribution (CC BY 4.0) licence. Anyone may reproduce, distribute, translate and create derivative works of this article (for both commercial and non-commercial purposes), subject to full attribution to the original publication and authors. The full terms of this licence may be seen at http://creativecommons.org/licences/by/4.0/ legalcode.

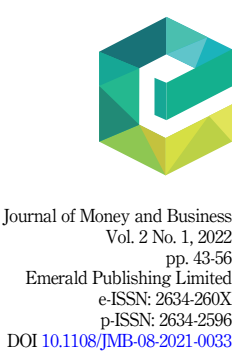


JMB 2,1

statements identifies timeliness as a constraint on relevant information and states that if the financial information is not reported on a timely basis, it may lose its relevance. Similarly, the Statement of Financial Accounting Concepts No. 2 (FASB, 1980) defines timeliness as having information available to decision-makers before it loses its capacity to influence decisions. If information is not available when it is needed or becomes available too long after the reported events, it has no value for decision-making. Thus, timeliness means that financial information must be made available to users as soon as possible from the end of the company's financial year, otherwise the usefulness of this information will be impaired. Empirical studies confirm that timely financial reporting reduces investment decision uncertainty (e.g. Al-Ajami, 2008; Ashton et al., 1989) and reduces information asymmetry in the capital market (e.g. Abernathy et al., 2014; Jaggi and Tsui, 1999). In addition, timely financial reports help mitigate the occurrence of leakage, rumors and insider trading in the capital market (e.g. Oraki and Zamanpoor, 2016; Owusu-Ansah, 2000). Given that the timeliness is one of the major determinants of financial reporting quality, this issue has received a great deal of attention in the literature. Prior studies have examined the factors affecting timeliness such as audit committee characteristics (e.g. Jao et al., 2021; Ashraf et al., 2020; Bhuiyan and D'Costa, 2020; Chukwu and Nwabochi, 2019; Baatwah et al., 2019; Oussii and Taktak, 2018; Ghafran and Yasmin, 2018; Salleh et al., 2017; Abernathy et al., 2014; Ika and Ghazali, 2012), board characteristics (e.g. Borgi et al., 2021; Mathuva et al., 2019; Alsmady, 2018; Sakka and Jarboui, 2016; Azeez, 2015; Baatwah et al., 2015; Elzahar and Hussainey, 2012), auditor characteristics (e.g. Kusuma and Indayani, 2020; Church et al., 2020; Rusmin and Evans, 2017) and corporate characteristics (e.g. Kusuma and Indayani, 2020; Mitra et al., 2012; Iyoha, 2012).

However, most of the prior studies that examined the timeliness of financial reports were conducted in developed countries. If financial reporting timeliness is an important issue for capital markets in developed countries, then this issue is more important for capital markets in developing countries. In the context of developing countries, financial reports are the only reliable source of financial information available in the market. Therefore, the provision of timely information in the corporate report assumes more importance since other sources, such as media releases, news conferences and financial analysts, are not well developed, and the regulatory bodies are not as effective as in developed countries (Al Daoud et al., 2015; Leventis et al., 2005; Wallace, 1993). The purpose of this study is to examine the impact of the company's characteristics on the timeliness of financial reports in Saudi Arabia as one of the developing countries. In fact, this study contributes to the literature on the financial reporting timeliness by examining this issue in Saudi Arabia as one of developing countries. Saudi Arabia is one of the leading Islamic countries. The Saudi Stock Exchange is the largest and only Middle East and North Africa (MENA) country in the G20. It is also the largest most liquid market in the MENA. Saudi Arabia is a key member of the Organization of the Petroleum Exporting Countries (OPEC) that has around 25\% of the world's oil reserves, and it represents one of the largest oil producers in OPEC (Ibrahim et al., 2019). Despite the importance of financial reporting timeliness, this issue has not received sufficient attention in Saudi Arabia. There are very few studies on this issue in Saudi Arabia. Specifically, Alnajran and Faleel (2021) examined a sample of 15 companies in the period 2010-2014 and found that the most important factor affecting the timeliness of audit report was the complexity of the company's activity. Borgi et al. (2021) examined the relationship between chief executive officer (CEO) characteristics and the timeliness of financial reports and found that companies with a $\mathrm{CEO}$ who is an accounting financial expert reduce the period taken to prepare and disclose their financial reports and that CEO sociability is significantly associated with timely financial reporting. Accordingly, this study attempts to fill this gap in the studies of timeliness in Saudi Arabia by examining the impact of the company's characteristics on the timeliness of the financial reporting. To achieve the purpose of the study, the remainder of the study was organized as follows: The second section presents literature review and hypothesis 
development. The third section shows study methodology. The fourth section introduces the results of the study, while the fifth section presents the conclusion and limitations.

\section{Literature review and hypothesis development}

Corporate characteristics are among the contributing factors in the studies of financial reporting timeliness. Prior studies examined the relationship between financial reports timeliness and a number of corporate characteristics. The most important characteristics of the company that have been examined in the timeliness literature are as follows:

\subsection{Company size}

Prior studies showed that there is a positive correlation between the size of the company and timeliness of financial reports. Prior studies provided several reasons to justify this positive relationship. Ku Ismail and Chandler (2004) argued that large companies typically have more resources, more accounting staff and more advanced accounting information systems than their smaller counterparts. Hence, large companies have the ability to prepare and publish their financial statements in a shorter period of time than their counterparts. A similar argument is proposed by Owusu-Ansah (2000) suggesting that large companies tend to have strong systems of internal control. As a result, external auditors spend fewer times in conducting substantive tests. Also, larger companies are more capable of exerting pressures on the external auditor to begin auditing and to complete it on time (Carslaw and Kaplan, 1991; Ashton et al., 1989). Large companies are more likely to own strict procedures and formal policies that will facilitate early completion (Afify, 2009; Al-Ajmi, 2008). Large companies are more in the spotlight by the public; therefore, large companies tend to maintain the company's image in the eyes of the public by submitting their financial reports in a timely manner (Nelson et al., 2019). In fact, studies that have empirically examined the relationship between company size and financial reporting timeliness in developing countries have produced mixed results. Some studies have provided empirical evidence of a positive relationship between company size and financial reporting timeliness, such as Abdullah (1996) in Bahrain, Owusu-Ansah and Leventis (2006) in Greece, Akle (2011) in Egypt, Ahmed (2003) in three South Asian countries, namely, Bangladesh, India and Pakistan, Güleç (2017) in Turkey, Ahmad et al. (2018) in Malaysia, Ha et al. (2018) in Vietnam and Murti (2021) in Indonesia. On the contrary, other studies provided empirical evidence that there is no significant effect of company size on financial reporting timeliness, such as Rahmawati (2018) and Bangun (2019) in Indonesia. In light of the conflicting results of previous studies, the first hypothesis of the study can be formulated in the form of the null hypothesis as follows:

H01. There is no association between financial reporting timeliness and size of the reporting company.

\subsection{Profitability}

According to signaling theory, the publication of a company's earnings to the market contains new information. The company's management can use profitability to signal and give good news to the market. Managers signal the unobservable quality of their companies to potential investors via the observable quality of their financial statements (Zhang and Wiersema, 2009). When companies signal high quality, they receive returns from the market. Under these circumstances, high profitability companies have an incentive to signal early in order to obtain market returns as opposed to low profitability companies who try to delay signaling in order to delay punishment from the market (Scott, 2015; Brigham and Houston, 2013; Ross, 1977). Accordingly, a positive relationship can be expected between profitability 
$\mathrm{JMB}$ 2,1

and financial reporting timeliness. High profitability companies have an incentive to publish financial reports earlier than their low profitability peers. Owusu-Ansah (2000) argued that companies with high profitability will report this information earlier than those with low profitability or losses to report. This is because the efficiency of a company's operations is usually measured by its profitability. Similarly, Ku Ismail and Chandler (2004) argued that companies are more relaxed when declaring satisfactory information rather than unsatisfactory information. Earning higher than the expected earnings is good news for investors. It is expected that companies will be eager to disseminate such information without any delay and will be reluctant to spread "bad news" or "not good." Basu (1997) found that companies tend to release good news earlier than bad news, and the reason was conservatism. When companies have unexpected growth, they disclose their information earlier and attract more investors by announcing their remarkable growth, and when they have less growth, they perform more conservative in presenting their reports. In fact, studies that have empirically examined the relationship between profitability and financial reporting timeliness in developing countries have produced mixed results. Some studies have provided empirical evidence of a positive relationship between profitability and the timeliness of financial reports, such as Abdullah (1996) and Khasharmeh and Aljifri (2010) in Bahrain, Al Daoud et al. (2014) in Jordan, Güleç (2017) in Turkey, Ha et al. (2018) in Vietnam, Abdillah et al. (2019) and Bangun (2019) in Indonesia and Agyei-Mensah (2018) in Ghana. On the other hand, other studies provided empirical evidence that there is no significant effect of profitability on financial reporting timeliness, such as Ahmed (2003) in Bangladesh and India, Khasharmeh and Aljifri (2010) in the United Arab Emirates and Rahmawati (2018) in Indonesia. In light of the conflicting results of previous studies, the second hypothesis of the study can be formulated in the form of the null hypothesis as follows:

H02. There is no association between financial reporting timeliness and profitability of the reporting company.

\subsection{Leverage}

According to agency theory, agency costs increase with increasing leverage because shareholders have more incentives to transfer wealth from creditors and will be more likely to engage in riskier activities that promise high returns with that financial structure (Jensen and Meckling, 1976). Thus, highly indebted companies will be keen to reduce the doubts of debtholders by providing them with information faster (Ashbaugh and Warfield, 2003). Debtholders may also require highly indebted companies to report in a timely and faster manner to protect their rights (Owusu-Ansah and Leventis, 2006). Accordingly, it is expected that there will be a positive relationship between leverage and timeliness of financial reports, as companies with high leverage tend to publish financial reports faster than companies with low leverage (Akle, 2011). Abdullah (1996) argued that an increase in the amount of debt a company uses in its operations will put pressure on it to provide the company's creditors with audited financial statements at the time of their due. Informed big-equity investors, especially institutional equity investors, tend to monitor this matter because the delay in publishing the financial reports leads to an increase in the cost of borrowing and then negatively affects the price of their shares in the market. In fact, empirical studies that examined the relationship between leverage and the financial reporting timeliness in developing countries confirmed the existence of the positive relationship between them, such as Abdulla (1996) and Al-Ajmi (2008) in Bahrain, Ismail and Chandler (2004) in Malaysia, Khasharmeh and Aljifri (2010) in the United Arab Emirates and Bahrain, Alkhatib and Marji (2012) in Jordan, Ha et al. (2018) in Vietnam and Abdillah et al. (2019) in Indonesia. In light of the above discussion, the third hypothesis of the study can be formulated in the form of the null hypothesis as follows: 
H03. There is no association between the financial reporting timeliness and leverage of the reporting company.

\subsection{Institutional ownership}

Institutional investors consist of pension funds, trust institutions, insurance companies, financial and investment companies. According to agency theory, the agency problem can be overcome through institutional ownership. Institutional investors are seen as an effective corporate governance mechanism. Because of the large stake they hold in the company, they are motivated to monitor management's behavior. Institutional ownership monitoring provides proactive monitoring that cannot be provided by less-informed investors. A high level of institutional ownership will lead to greater oversight efforts by the institutional side of the company, so that it can hinder managers' opportunistic behavior (Alves, 2012). Zureigat (2011) argued that institutional ownership can be strongly involved in controlling and correcting management choices and in directing the reporting of a company's financial activities because they are more knowledgeable than individual investors. Mitra et al. (2012) document the association between the corporate ownership characteristics and the timely remediation of internal control weaknesses over financial reporting. Thanatawee (2014) states that large contributions by institutional investors will have incentives to monitor the company's decision making. This will limit the weak performance of the agent and then reflected in the improvement of the company's performance and increase in profits. Empirical studies that examined the relationship between institutional ownership and financial reporting timeliness provided evidence of a positive relationship between the percentage of institutional ownership in the company's ownership structure and financial reporting timeliness, such as Al-Ajmi (2008) in Bahrain, Ezat and El-Masry (2008) in Egypt, Kusuma and Indayani (2020) in Indonesian and Aksoy et al. (2021) in Turkey. In light of the above discussion, the fourth hypothesis of the study can be formulated in the form of the null hypothesis as follows:

H04. There is no association between the financial reporting timeliness and institutional ownership in the reporting company.

\section{Research methods}

\subsection{Sample and data}

The study aims to examine the relationship between financial reporting timeliness and some characteristics of the company, namely company size, profitability, leverage and institutional ownership. The study data were collected from the Saudi Stock Exchange (Tadawul) for a period of four years 2015-2018. The years 2019 and 2020 were excluded, as these two years witnessed the capital market affected by the Covid-19 pandemic, which led to a delay in the publication of financial reports for most listed companies. The study population includes all companies listed in the Saudi Stock Exchange (Tadawul). By the end of 2018, the number of companies listed in the Saudi Stock Exchange reached 173 companies distributed over 20 sectors. In the first step for selecting the sample, 45 financial companies (i.e. banks, insurance companies, financial services companies and real estate funds) were excluded, as the nature of some items of the financial statements of these companies differed to some extent from the financial statements of nonfinancial companies due to their subjection to special legislation in addition to the International Financial Reporting Standards (IFRS). In the second step, 61 other companies were excluded from the study population for various reasons, such as some companies were listed in the stock market after the year 2015, and then their published financial statements on the Saudi Stock
Timeliness of financial reporting 
JMB 2,1
Exchange website do not cover the entire study period. Also, some companies were merged into other companies during the study period and then no longer had their own published financial statements. In addition, some companies whose registration in the financial market was canceled during the study period. After these two steps, the remaining 67 nonfinancial companies represent the sample for this study. Table 1 shows the distribution of the study sample among sectors. As shown in Table 1, the final sample of the study consists of 67 nonfinancial companies distributed over 11 sectors representing all sectors of nonfinancial companies listed in the Saudi market.

\subsection{Variables and model}

The variables examined in this study consist of one dependent variable, which is financial reporting timeliness, and four independent variables, namely, company size, profitability, leverage and institutional ownership. In addition to these main independent variables, the model includes another set of control variables. The first control variable is the size of the audit firm. Big audit firms are likely to have resources and capabilities to conduct their audits in a shorter time. Hence, clients of big auditors are expected to have timely financial reporting. The second control variable is the type of audit opinion that the company obtained. Companies that did not receive an unqualified audit opinion are more likely to have had financial reporting issues and therefore needed additional time to submit their financial reports. The third control variable is the implementation of IFRS. Saudi companies are mandated to implement IFRS starting from January 1, 2017. It is expected that the implementation of IFRS will result in more disclosures in addition to some changes in the method some items are measured. This can lead to companies needing more time to submit their financial reports. Based on that, the study uses the following regression model to test the association between corporate characteristics and financial reporting timeliness:

$$
\begin{aligned}
\text { TIME }= & a+\beta_{1} \mathrm{SIZE}+\beta_{2} \mathrm{PROF}+\beta_{3} \mathrm{LVR}+\beta_{4} \mathrm{INIST}+\beta_{5} \mathrm{AUSIZE}+\beta_{6} \mathrm{AUOPINION} \\
& +\beta_{7} \mathrm{IFRS}+\varepsilon
\end{aligned}
$$

where

$$
\begin{aligned}
& \text { TIME = financial reporting timeliness } \\
& \text { SIZE = company size. } \\
& \text { PROF = profitability. }
\end{aligned}
$$

\begin{tabular}{lcc}
\hline Sector & Number of companies & Percentage \\
\hline Basic industries & 25 & 37.3 \\
Telecommunications & 4 & 5.9 \\
Food production & 12 & 17.9 \\
Transportation & 5 & 7.5 \\
Real estate development & 6 & 8.9 \\
Capital goods & 7 & 10.5 \\
Retail trade & 3 & 4.5 \\
Healthcare & 2 & 3 \\
Pharmaceutical & 1 & 1.5 \\
Applications and technology services & 1 & 1.5 \\
Media and entertainment & 1 & 1.5 \\
Total & 67 & 100 \\
\hline
\end{tabular}

Table 1.

Distribution of the sample across sectors 
$\mathrm{LVR}=$ leverage

INIST $=$ institutional ownership. financial

AUSIZE $=$ audit firm size. reporting

AUOPINION $=$ type of audit opinion.

IFRS $=$ implementation of IFRS.

\subsection{Variable measurement}

3.3.1 Timeliness. Timeliness is measured by calculating the number of days between a firm's fiscal year end and the audit report date. Audit report date is often viewed as the most important determinant of financial reporting timeliness because the capital market authorities in all countries do not allow public companies to issue their financial reports until after the conclusion of the external audit.

3.3.2 Company size. The most common measure of firm size in previous studies is the $\mathrm{Ln}$ of total assets (e.g. Murti, 2021; Ahmad et al., 2018; Ha et al., 2018; Güleç, 2017; Akle, 2011). Consistent with previous studies, this study measures company size using $\log 10$ of the book value of the total assets at the end of the fiscal year from the published financial statements of the company.

3.3.3 Profitability. The most widely used profitability metric in previous studies is the rate of return on assets (ROA), where this measure refers to the company's efficiency in exploiting its assets to generate profits. Consistent with previous studies, profitability will be measured in this study through the ROA (e.g. Bangun, 2019; Abdillah et al., 2019; Ha et al., 2018; AgyeiMensah, 2018; Güleç, 2017) In this study, ROA was measured as follows:

$$
\mathrm{ROA}=\text { Net Income after Taxes and Zakat/Average Total Assets }
$$

3.3.4 Leverage. Consistent with previous studies, the study used the debt ratio as a measure of leverage (e.g. Abdillah et al., 2019; Ha et al., 2018; Alkhatib and Marji, 2012; Khasharmeh and Aljifri, 2010). The debt ratio was measured in this study as follows:

$$
\text { Debt Ratio }=\text { Total Debt } / \text { Total Assets }
$$

3.3.5 Institutional ownership. Consistent with previous studies, the study used the percentage of institutional ownership in the company's shares as a measure of institutional ownership (e.g. Aksoy et al., 2021; Kusuma and Indayani, 2020; Al-Ajmi, 2008; Ezat and El-Masry, 2008). The percentage of institutional ownership was measured in this study as follows:

Percentage of institutional ownership = Number of shares owned by the institutions /

Total number of shares of the company.

3.3.6 Audit firm size. The size of the audit firm was measured by a dummy variable that takes the value 1 if the company's financial statements were audited by one of the big 4 auditors and the value 0 otherwise.

3.3.7 Type of audit opinion. The type of audit opinion was measured by a dummy variable that takes the value 1 if the company obtained an unqualified opinion and the value 0 otherwise.

3.3.8 Implementation of IFRS. Implementation of IFRS was measured through a dummy variable that takes a value of 1 in the years 2015-2016 (premandatory adoption of IFRS) and a value of 0 in the years 2017-2018 (postmandatory adoption of IFRS). 
$\mathrm{JMB}$
2,1

50

\section{Analysis and results}

4.1 Descriptive statistics

Table 2 presents descriptive statistics for the study variables. It reports the minimum, maximum, mean and standard deviation of the eight variables of the study (one dependent variable and seven independent variables). As shown in Table 2, the mean of financial reporting timeliness is 58 days. This result is lower than Borgi et al. (2021) in Saudi Arabia (65 days). In Borgi et al. (2021)'s study, financial reporting timeliness was measured by the number of days between a firm's financial year end and the date of disclosing the annual reports to the public (on Saudi Stock Exchange website). This measure captures the time taken by the auditor and management to issue the audited annual reports to the public, which includes a delay in audit work and a delay in negotiating the accounting issues after the audit work.

\subsection{Correlation analysis}

The study performed a multicollinearity test to examine the correlation among the independent variables. Table 3 presents the matrix of correlations and variance inflation factor (VIF). As shown in Table 3, all independent variable shows a VIF value smaller than 10, which means that there is no multicollinearity at significant level $p \leq 0.05$. Through VIF values, it can be concluded that the regression model is free from the assumption of multicollinearity. From Table 3, it is noted that the company's size is positively and significantly correlated with audit firm size at the level of significance $p \leq 0.05$ and with the company's profitability at the level of significance $p \leq 0.10$. It is also noted that the company's profitability is positively and significantly correlated with institutional ownership at the level of significance $p \leq 0.10$, while it is negatively and significantly correlated with the implementation of IFRS at significance level $p \leq 0.10$. Also, the financial leverage is positively and significantly correlated with both auditor's opinion type and the implementation of IFRS

Table 2.

Descriptive statistics

\begin{tabular}{lccccc}
\hline Variable & Observations (company/year) & Minimum & Maximum & Mean & Std. deviation \\
\hline TIME & 268 & 21 days & 79 days & 58 days & 16 days \\
SIZE & 268 & 14.71 & 26.43 & 19.62 & 4.356 \\
PROF & 268 & -0.29 & 0.43 & 0.24 & 0.127 \\
LVR & 268 & 0.17 & 0.41 & 0.28 & 0.109 \\
INIST & 268 & 0.13 & 0.67 & 0.31 & 1.041 \\
AUSIZE & 268 & 0.57 & 0.89 & 0.68 & 0.287 \\
AUOPINION & 268 & 0.48 & 0.76 & 0.63 & 0.175 \\
IFRS & 268 & 0.39 & 0.50 & 0.48 & 0.161 \\
\hline
\end{tabular}

\begin{tabular}{|c|c|c|c|c|c|c|c|c|}
\hline & SIZE & PROF & LVR & INIST & AUSIZE & AUOPINION & IFRS & VIF \\
\hline SIZE & 1.00 & & & & & & & 2.02 \\
\hline PROF & $0.214^{* *}$ & 1.00 & & & & & & 1.23 \\
\hline LVR & 0.019 & 0.124 & 1.00 & & & & & 1.45 \\
\hline INIST & 0.234 & $0.301^{* *}$ & 0.216 & 1.00 & & & & 1.98 \\
\hline AUSIZE & $0.591^{*}$ & 0.298 & 0.421 & $0.251^{*}$ & 1.00 & & & 2.78 \\
\hline AUOPINION & 0.194 & 0.169 & $0.429 * *$ & 0.198 & 0.263 & 1.00 & & 1.96 \\
\hline IFRS & 0.167 & $-0.221 * *$ & $0.192 * *$ & 0.138 & 0.167 & 0.172 & 1.00 & 1.84 \\
\hline
\end{tabular}

Table 3.

Correlation analysis

Note(s): *Represents significant at $p \leq 0.05$
$* *$ Represents significant at $p \leq 0.10$ 
at the level of significance $p \leq 0.10$. With regard to the rest of the correlation coefficients, it is noted from Table 3 that they are positive but not significant, whether at the level of significance $p \leq 0.05$ or $p \leq 0.10$.

\subsection{Multivariate regression analyses}

Table 4 presents the results of multiple regressions analysis. As shown in Table 4, the study model is significant as the $F$-statistics are significant at a significance level $p \leq 0.05$. Table 4 shows that the coefficient of the company's size is - 3.06 , and this coefficient is significant at a significance level of $p \leq 0.05$, which indicates that the size of the company has a negative and significant impact on the time period taken by the company to publish its financial reports. This result leads to the rejection of the first null hypothesis, which states that there is no relationship between the size of the company and financial reporting timeliness. This result confirms the results of previous studies in other developing countries, which concluded that there is a positive relationship between the size of the company and the timeliness of financial reporting such as Abdullah (1996) in Bahrain, Owusu-Ansah and Leventis (2006) in Greece, Akle (2011) in Egypt, Ahmed (2003) in three South Asian countries, namely Bangladesh, India and Pakistan, Güleç (2017) in Turkey, Ahmad et al. (2018) in Malaysia, Ha et al. (2018) in Vietnam and Murti (2021) in Indonesia.

As can be seen from Table 4, the profitability coefficient is -2.21 , and this coefficient is significant at a significance level of $p \leq 0.05$, which indicates that the company's profitability has a negative and significant impact on the time period taken by the company to publish its financial reports. This result leads to the rejection of the second null hypothesis, which states that there is no relationship between profitability and financial reporting timeliness. This result confirms the results of previous studies in other developing countries that concluded that there is a positive relationship between profitability and the timeliness of financial reports, such as Abdullah (1996) and Khasharmeh and Aljifri (2010) in Bahrain, Al Daoud et al. (2014) in Jordan, Güleç (2017) in Turkey, Ha et al. (2018) in Vietnam, Abdillah et al. (2019) and Bangun (2019) in Indonesia and Agyei-Mensah (2018) in Ghana. Regarding leverage and as can be seen from Table 4, the leverage coefficient is 4.01, and this coefficient is significant at a significance level of $p \leq 0.05$, which indicates that the company's leverage has a positive and significant impact on the time period taken by the company to publish its financial reports. This result leads to the rejection of the third null hypothesis, which states that there is no relationship between leverage and financial reporting timeliness. This result confirms the results of previous

\begin{tabular}{lccc}
\hline Variable & Coefficient & $t$-statistic & Sig \\
\hline SIZE & -3.06 & -2.49 & $0.00^{*}$ \\
PROF & -2.21 & -1.98 & $0.03^{*}$ \\
LVR & 4.01 & 3.32 & $0.01^{*}$ \\
INIST & -2.69 & 1.69 & 0.08 \\
AUSIZE & -3.264 & -4.59 & $0.00^{*}$ \\
AUOPINION & -2.968 & 6.35 & $0.00^{*}$ \\
IFRS & 5.019 & 3.89 & 0.09
\end{tabular}

Observations 268

Companies 67

$R$-squared 0.2481

$F$-statistic $3.26^{*}$

Note(s): *Represents significant at $p \leq 0.05$
Timeliness of financial reporting 
$\mathrm{JMB}$ 2,1

52

studies in other countries that concluded that there is a negative relationship between leverage and the timeliness of financial reports, such as Abdulla (1996) and Al-Ajmi (2008) in Bahrain, Ismail and Chandler (2004) in Malaysia, Khasharmeh and Aljifri (2010) in the United Arab Emirates and Bahrain, Alkhatib and Marji (2012) in Jordan, Ha et al. (2018) in Vietnam and Abdillah et al. (2019) in Indonesia. Finally, it is noted that the coefficient of institutional ownership is -2.69 , and this coefficient is not significant at a significance level of $p \leq 0.05$. This result leads to accept the fourth null hypothesis, which states that there is no significant relationship between institutional ownership and financial reporting timeliness. In fact, this result contradicts the results of previous studies conducted in other developing countries, such as Al-Ajmi (2008) in Bahrain, Ezat and El-Masry (2008) in Egypt, Kusuma and Indayani (2020) in Indonesia and Aksoy et al. (2021) in Turkey. This result indicates that the size of the shares owned by the institution cannot guarantee that the institution is able to carry out its supervisory function on the company's management properly. With regard to the control variables, it is noted that the coefficients for each of the audit firm size and the audit opinion are -3.264 and -2.968 , respectively, and these coefficients are significant at the level of significance $p \leq 0.05 .5$, while the coefficient for the IFRS was 5.019, and this coefficient is not significant at the level of significance $p \leq 0.05 .5$. These results indicate that both the size of the audit firm and the audit opinion have a positive and significant impact on the timeliness of financial reports, while the implementation of IFRS has no significant impact on the timeliness of financial reports. These results are consistent with Borgi et al. (2021) and Oussii and Taktak (2018) who suggest that qualified audit opinion may need extra time from auditors before finishing their audit work for the companies that received this type of audit opinions, which may affect the audit report lag and so the financial reporting timeliness. Also, the results are consistent with the results of Borgi et al. (2021), Baatwah et al. (2015) and Afify (2009) who suggest that larger audit firms may complete the audit work earlier than smaller audit firms.

\section{Conclusion and limitations}

Timeliness is one of the most important characteristics of the quality of information included in published financial reports. The faster financial reports are published, the more useful of its information in making economic decisions. Consequently, the issue of timeliness has received great attention from both regulatory authorities and academic research. Despite the importance of timeliness, this issue has not received sufficient attention in Saudi Arabia. This study aimed to examine the impact of the company's characteristics on the timeliness of financial reports in the Saudi Stock Exchange. Based on a sample of 67 companies listed in the Saudi Stock Exchange during the period 2015-2018, the study concluded that there are three characteristics of the company that significantly affect the timeliness of the financial reports, the size of the company, the company's profitability and the company's leverage. This study contributes to studies of financial reporting timeliness in developing countries, in general, and to studies of financial reporting timeliness in Saudi Arabia in particular. However, this study is not without limitations. The first limitation is that this study focused on nonfinancial companies only and excluded financial companies from the sample, which weakens the possibility of generalizing the results of the study to the Saudi Stock Exchange as a whole. Future studies can examine the timeliness of financial reports in these financial companies. The second limitation is that this study examined only four characteristics of companies, namely size, profitability, leverage and institutional ownership. Future studies can examine the effect of other characteristics of the company on the timeliness of financial reports. Finally, this study focused only on annual financial reports. Future studies can examine the determinants of timeliness with respect to quarterly financial reports. 


\section{References}

Abdillah, M., Mardijuwono, W. and Habiburrochman, H. (2019), "The effect of company characteristics and auditor characteristics to audit report lag", Asian Journal of Accounting Research, Vol. 4 No. 1, pp. 129-144.

Abdulla, J. (1996), "The timeliness of Bahraini annual reports", Advances in International Accounting, Vol. 9, pp. 73-88.

Abernathy, J., Beyer, B., Masli, A. and Stefaniak, C. (2014), "The association between characteristics of audit committee accounting experts, audit committee chairs, and financial reporting timeliness", Advances in Accounting, Vol. 30 No. 2, pp. 283-297.

Afify, H. (2009), "Determinants of audit report lag: does implementing corporate governance have any impact? Empirical evidence from Egypt”, Journal of Applied Accounting Research, Vol. 10 No. 1, pp. $56-86$.

Agyei-Mensah, B. (2018), "Impact of corporate governance attributes and financial reporting lag on corporate financial performance", African Journal of Economic and Management Studies, Vol. 9 No. 3, pp. 349-366.

Ahmad, S., Yunos, S. and Yunos, R. (2018), "Timeliness of financial reporting in the Shariah-compliant companies: effects of audit committee's and firms' characteristics", Insight Journal, Vol. 1 No. 1, pp. 23-33.

Ahmed, K. (2003), "The timeliness of corporate reporting: a comparative study of South Asia", Advances in International Accounting, Vol. 16 No. 1, pp. 17-43.

Akle, Y. (2011), "The relationship between financial reporting timeliness and attributes of companies listed on Egyptian stock exchange' an Empirical Study", Internal Auditing and Risk Management, Vol. 23 No. 3, pp. 83-103.

Aksoy, M., Yilmaz, M., Topcu, N. and Uysal, Ö. (2021), "The impact of ownership structure, board attributes and XBRL mandate on timeliness of financial reporting: evidence from Turkey", Journal of Applied Accounting Research, Vol. 22 No. 4, pp. 706-731.

Al Daoud, K., Ismail, K. and Lode, N. (2014), "The timeliness of financial reporting among Jordanian companies: do company and board characteristics, and audit opinion matter?", Asian Social Science, Vol. 10 No. 13, pp. 191-201.

Al Daoud, K., Ismail, K. and Lode, N. (2015), "The impact of internal corporate governance on the timeliness of financial reports of Jordanian firms: evidence using audit and management report lags", Mediterranean Journal of Social Sciences, Vol. 6 No. 1, pp. 430-442.

Al-Ajmi, J. (2008), "Audit and reporting delays: evidence from an emerging market", Advances in Accounting, Vol. 24 No. 2, pp. 217-226.

Alkhatib, K. and Marji, Q. (2012), "Audit reports timeliness: empirical evidence from Jordan”, ProcediaSocial and Behavioral Sciences, Vol. 62, pp. 1342-1349.

Alnajran, M. and Faleel, J. (2021), "Determinants of audit report timeliness in Saudi Arabia: evidence from selected quoted companies”, Palarch's Journal of Archaeology of Egypt/Egyptology, Vol. 18 No. 13 , pp. 510-515.

Alsmady, A. (2018), "The effect of board of directors' characteristics and ownership type on the timeliness of financial reports", International Journal of Business and Management, Vol. 13 No. 6, pp. 276-287.

Alves, S. (2012), "Ownership structure and earnings management: evidence from Portugal", Australasian Accounting Business and Finance Journal, Vol. 6 No. 1, pp. 57-74.

Ashbaugh, H. and Warfield, T. (2003), "Audits as a corporate governance mechanism: evidence from the German Market”, Journal of International Accounting Research, Vol. 2 No. 1, pp. 1-21.

Ashraf, M., Michas, P. and Russomanno, D. (2020), "The impact of audit committee information technology expertise on the reliability and timeliness of financial reporting", The Accounting Review, Vol. 95 No. 5, pp. 23-56.
Timeliness of financial reporting 
$\mathrm{JMB}$ 2,1

Ashton, R., Graul, P. and Newton, J. (1989), "Audit delay and timeliness of corporate reporting", Contemporary Accounting Research, Vol. 5 No. 2, pp. 657-673.

Azeez, A. (2015), "Corporate governance and firm performance: evidence from Sri Lanka", Journal of Finance and Bank Management, Vol. 3 No. 1, pp. 180-189.

Baatwah, S., Salleh, Z. and Ahmad, N. (2015), "CEO characteristics and audit report timeliness: do CEO tenure and financial expertise matter?”, Managerial Auditing Journal, Vol. 30 Nos 8/9, pp. 998-1022.

Baatwah, S., Salleh, Z. and Stewart, J. (2019), "Audit committee chair accounting expertise and audit report timeliness: the moderating effect of chair characteristics", Asian Review of Accounting, Vol. 27 No. 2, pp. 273-306.

Bangun, M. (2019), "The effect of earning management, profitability, and firm size on audited financial statement timeliness", International Journal of Innovative Science and Research Technology, Vol. 4 No. 7, pp. 49-59.

Basu, S. (1997), "The conservatism principle and the asymmetric timeliness of earnings", Journal of Accounting and Economics, Vol. 24 No. 1, pp. 3-37.

Bhuiyan, M. and D'Costa, M. (2020), “Audit committee ownership and audit report lag: evidence from Australia", International Journal of Accounting and Information Management, Vol. 28 No. 1, pp. 96-125.

Borgi, H., Ghardallou, W. and AlZeer, M. (2021), "The effect of CEO characteristics on financial reporting timeliness in Saudi Arabia”, Accounting, Vol. 7, pp. 1265-1274.

Brigham, E. and Houston, J. (2013), Fundamentals of Financial Management, Concise 8th ed., SouthWestern Cengage Learning, Amerika.

Carslaw, C. and Kaplan, S. (1991), "An examination of audit delay: further evidence from New Zealand”, Accounting and Business Research, Vol. 22, pp. 21-32.

Chukwu, G. and Nwabochi, N. (2019), "Audit committee characteristics and timeliness of corporate financial reporting in the Nigerian insurance industry", International Journal of Managerial Studies and Research, Vol. 7 No. 4, pp. 86-95.

Church, B., Dai, N. and Kuang, X. (2020), "The role of auditor Narcissism in auditor-client negotiations: evidence from China”, Contemporary Accounting Research, Vol. 37 No. 3, pp. 1756-1787.

Elzahar, H. and Hussainey, K. (2012), "Determinants of narrative risk disclosures in UK interim reports", Journal of Risk Finance, Vol. 13 No. 2, pp. 133-147.

Ezat, A. and El-Masry, A. (2008), "The impact of corporate governance on the timeliness of corporate internet reporting by Egyptian listed companies", Managerial Finance, Vol. 34 No. 12, pp. 848-867.

FASB (1980), Statement of Financial Accounting Concepts No. 2, American Accounting Association, Sarasota, FL.

Ghafran, C. and Yasmin, S. (2018), "Audit committee chair and financial reporting timeliness: a focus on financial, experiential and monitoring expertise", International Journal of Auditing, Vol. 22 No. 1, pp. 13-24.

Güleç, O. (2017), "Timeliness of corporate reporting in developing economies: evidence from Turkey", Journal of Accounting and Management Information Systems, Vol. 16 No. 3, pp. 219-239.

Ha, H., Hung, D. and Phuong, N. (2018), "The study of factors affecting the timeliness of financial reporting: the experiments on listed companies in Vietnam", Asian Economic and Financial Review, Vol. 8 No. 2, pp. 294-307.

IASB (2010), "The objective of financial reporting and qualitative characteristics of decision-useful financial information", London, available at: www.iasb.org/Home.htm.

Ibrahim, A., Habbash, M. and Hussainey, K. (2019), "Corporate governance and risk disclosure: evidence from Saudi Arabia”, International Journal of Accounting, Auditing and Performance Evaluation, Vol. 15 No. 1, pp. 89-111. 
Ika, S. and Ghazali, N. (2012), "Audit committee effectiveness and timeliness of reporting: Indonesian evidence", Managerial Auditing Journal, Vol. 27 No. 4, pp. 403-424.

Ismail, K. and Chandler, R. (2004), "The timeliness of quarterly financial reports of companies in Malaysia", Asian Review of Accounting, Vol. 12 No. 1, pp. 1-18.

Iyoha, F. (2012), "Company attributes and the timeliness of financial reporting in Nigeria", Business Intelligence Journal, Vol. 5 No. 1, pp. 1-14.

Jaggi, B. and Tsui, J. (1999), "Determinants of audit report lag: further evidence from Hong Kong", Accounting and Business Research, Vol. 30 No. 1, pp. 17-28.

Jao, R., Kampo, K., Holly, A. and Susanto, A. (2021), "The effect of board of commissioner and audit committee effectiveness on timeliness of financial rreporting", International Journal of All Research Writings, Vol. 2 No. 9, pp. 39-44.

Jensen, M. and Meckling, W. (1976), "Theory of the firm: managerial behavior, agency costs and ownership structure", Journal of Financial Economics, Vol. 3 No. 4, pp. 305-360.

Khasharmeh, H. and Aljifri, K. (2010), "The timeliness of annual reports in Bahrain and the United Arab Emirates: an empirical comparative study", The International Journal of Business and Finance Research, Vol. 4 No. 1, pp. 51-71.

$\mathrm{Ku}$ Ismail, K. and Chandler, R. (2004), "The timeliness of quarterly financial reports of companies in Malaysia”, Asian Review of Accounting, Vol. 12 No. 1, pp. 1-18.

Kusuma, A. and Indayani, N. (2020), "The effect of public accountant reputation, audit opinion, and institutional ownership on timeliness of financial reporting and its impact on the value of the firm of manufacturing sectors in Indonesian stock exchange", IAR Journal of Business Management, Vol. 1 No. 4, pp. 259-265.

Leventis, S., Weetman, P. and Caramanis, C. (2005), "Determinants of audit report lag: some evidence from the Athens stock exchange", International Journal of Auditing, Vol. 9 No. 1, pp. $45-58$.

Mathuva, D., Tauringana, V. and Owino, F. (2019), "Corporate governance and the timeliness of audited financial statements: the case of Kenyan listed firms", Journal of Accounting in Emerging Economies, Vol. 9 No. 4, pp. 473-501.

Mitra, S., Hossain, M. and Marks, B. (2012), "Corporate ownership characteristics and timeliness of remediation of internal control weaknesses", Managerial Auditing Journal, Vol. 27 No. 9, pp. 846-877.

Murti, W. (2021), "Timeliness of corporate annual financial reporting in Indonesian banking industry", Accounting, Vol. 7, pp. 553-562.

Nelson, S., Ahmad, M. and Mohamed, H. (2019), "Relationship between the industry specialist auditors and financial reporting timeliness under MFRS", Pertanika Journal of Social Sciences and Humanities, Vol. 27 No. 1, pp. 16-27.

Oraki, M. and Zamanpoor, A. (2016), "An examination of the relationship between economic criteria evaluating the performance and delay- amount in releasing annual financial reports of listed companies in tehran stock exchange", Pacific Business Review International, Vol. 9 No. 4, pp. 56-65.

Oussii, A. and Taktak, N. (2018), "Audit committee effectiveness and financial reporting timeliness: the case of Tunisian listed companies", African Journal of Economic and Management Studies, Vol. 9 No. 1, pp. 34-55.

Owusu-Ansah, S. (2000), "Timeliness of corporate financial reporting in emerging capital markets: empirical evidence from the Zimbabwe Stock Exchange", Accounting and Business Research, Vol. 30 No. 3, pp. 241-254.

Owusu-Ansah, S. and Leventis, S. (2006), "Timeliness of corporate annual financial reporting in Greece", European Accounting Review, Vol. 15 No. 2, pp. 273-287.

Timeliness of financial reporting 
$\mathrm{JMB}$ 2,1

Rahmawati, E. (2018), "Information content and determinants of timeliness financial reporting: evidence from an emerging market”, Academy of Accounting and Financial Studies Journal, Vol. 22 No. 4, pp. 1-16.

Ross, S. (1977), "The determination of financial structure: the incentive-signaling approach", The Bell Journal of Economics, Vol. 8 No. 1, pp. 23-40.

Rusmin, R. and Evans, J. (2017), "Audit quality and audit report lag: case of Indonesian listed companies", Asian Review of Accounting, Vol. 25 No. 2, pp. 191-210.

Sakka, I. and Jarboui, A. (2016), "Audit reports timeliness: empirical evidence from Tunisia”, Cogent Business and Management, Vol. 3, 1195680.

Salleh, Z., Baatwah, S. and Ahmad, N. (2017), "Audit committee financial expertise and audit report lag: Malaysia further insight”, Asian Journal of Accounting and Governance, Vol. 8, pp. 137-150.

Scott, W. (2015), Financial Accounting Theory, 7th ed., Pearson Education, Canada.

Thanatawee, C. (2014), "Institutional ownership and firm value in Thailand", Asian Journal of Business and Accounting, Vol. 7 No. 2, pp. 1-22.

Wallace, R. (1993), "Development of accounting standards for developing and newly industrialized countries", Research in Accounting in Emerging Economies, Vol. 2, pp. 121-165.

Zhang, Y. and Wiersema, M. (2009), "Stock market reaction to CEO certification: the signaling role of CEO background", Strategic Management Journal, Vol. 30, pp. 693-710.

Zureigat, Q. (2011), "The effect of ownership structure on audit quality: evidence from Jordan", International Journal of Business and Social Science, Vol. 2 No. 10, pp. 38-46.

\section{Further reading}

Chambers, A. and Penman, S. (1984), "Timeliness of reporting and the stock price reaction to earnings announcements", Journal of Accounting Research, Vol. 22 No. 1, pp. 21-47.

Cooke, T. (1996), "The influence of the Keiretsu on Japanese corporate disclosure", Journal of International Financial Management and Accounting, Vol. 7 No. 3, pp. 191-214.

Khlif, H. and Samaha, K. (2014), "Internal control quality, Egyptian standards on auditing and external audit delays: evidence from the Egyptian Stock Exchange", International Journal of Auditing, Vol. 18, pp. 139-154.

\section{Corresponding author}

Ibrahim El-Sayed Ebaid can be contacted at: ebaid1969@yahoo.com

For instructions on how to order reprints of this article, please visit our website:

www.emeraldgrouppublishing.com/licensing/reprints.htm

Or contact us for further details: permissions@emeraldinsight.com 